\title{
Atomi réteg leválasztás a nanotechnológiában
}

\author{
SZILÁGYI Imre Miklós* \\ Budapesti Müszaki és Gazdaságtudományi Egyetem, Szervetlen és Analitikai Kémia Tanszék, \\ 1111 Budapest, Müegyetem rakpart 3. Magyarország
}

\section{Az atomi réteg leválasztás története}

Az atomi réteg leválasztás (atomic layer deposition - ALD) elméletének alapjait Aleskovski már az 1950-es években lefektette a Szovjetunióban, Leningrádban (Szentpéterváron). Ezt követően ő és Koltsov az 1960-as években végezték az első kísérleteket az általuk molekuláris rétegzésnek (molecular layering - ML) nevezett módszerrel. Tőlük függetlenül Suntola és munkatársai is kifejlesztették az ALD alapelveit Finnországban, Helsinkiben az 1970-es években, és egyben ők voltak azok, akik lehetővé tették az ALD ipari alkalmazását. Először a rétegeket epitaxiásan növesztették, és emiatt a módszert atomi réteg epitaxiának (atomic layer epitaxy - ALE) hívták [1-4].

Az ALD első ipari felhasználására vékonyfilm elektrolumineszcens (thin film electroluminescent - TFEL) lapos kijelzők gyártásánál került sor. Bár már szinte a kezdetektől fogva az ALD alkalmazását számos más területen (pl. katalízis) is kutatták, a többi módszerhez képest az ALD hátránya a nagyon lassú filmnövekedési sebessége volt. A széleskörü elterjedésével meg kellett várni, amíg a növesztendő rétegek elvárt méretei annyira lecsökkentek, hogy az ALD alkalmazásával is megfelelő gyártási kapacitást lehessen elérni.

Így az igazi nemzetközi érdeklődés az ALD iránt csak az 1990-es években jött el, amikor eldöntötték, hogy a félvezetö ipar jövőjében kulcsszerepet szánnak az ALD-nek. Ahogyan a szilícium alapú mikroelektronikai eszközökben a méretek zsugorodtak, az addig használt vékonyfilm növesztési módszereknek és maguknak a vékonyfilmeket alkotó anyagoknak komoly problémákkal kellett szembenézniük. Egyrészt az addigi módszerekkel bizonyos méreten alul már nem tudtak egyenletes és homogén filmeket növeszteni, másrészt a vékonyfilmeket alkotó anyagok tulajdonságai túl kis méret esetén már nem voltak megfelelőek, pl. a $\mathrm{SiO}_{2}$ már nem szigetelt kellően. Ezért az ALD-t jelölték ki, hogy ez legyen a fö rétegnövesztési módszer számos anyag esetén, melyek különböző eszközökben szerepelnek, pl. félvezetö-oxid tranzisztorok (metal oxide semiconductor field effect transistors - MOSFETs) nagy dielektromos állandójú kapu oxidjai, réz diffúziós gátjai egyes csatlakozóknál, nagy mélység/szélesség arányú struktúrák memória kapacitásoknál, stb. Ennek köszönhetően a 2000-es években a vezető félvezető ipari vállalatok az ALD-t már széleskörüen alkalmazták egyes gyártási folyamataikban. Ezzel párhuzamosan az ALD a nanotechnológiában is egyre inkább az érdeklődés középpontjába került, ahol számos területen kezdték el alkalmazni, pl. szenzorok, tüzelőanyag cellák, napelemek, katalízis, nanobevonatok, kijelzők, LED-fényforrások, nanokompozitok, különféle nanoeszközök, stb. [5-9].

\section{Az ALD jellemzői}

Egy ALD-reakció négy egymást követő lépésből áll (1. ábra): (i) az első prekurzort pulzusszerüen bejuttatjuk egy általában vákuumozott reaktorba, ahol a szubsztrátum felületén kemiszorbeálódik; (ii) a prekurzor feleslegét vagy a felületi reakció gáznemü termékeit eltávolítjuk inert gázzal való öblítéssel és/vagy vákuumozással; (iii) a második prekurzor bejuttatása (pulzusa) következik, ami kizárólag a felületen elreagál az első prekurzorral; (iv) a második prekurzor feleslegét és a reakció melléktermékeket eltávolítjuk a gáztérből [10-13].

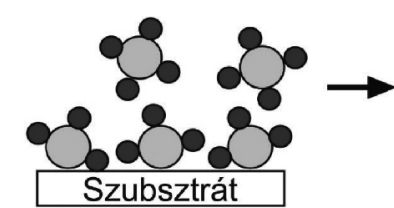

(1) első prekurzor pulzusa

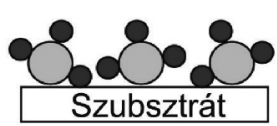

(2) öblítés

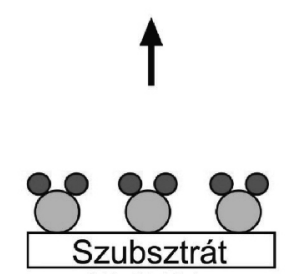

(4) öblítés

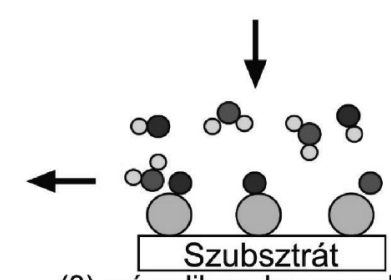

(3) második prekurzor pulzusa
1. Ábra. Az ALD egy ciklusának vázlata, mely során $\mathrm{TiCl}_{4}$ és $\mathrm{H}_{2} \mathrm{O}$ prekurzorok reakciójával $\mathrm{TiO}_{2}$-réteg jön létre a felületen (szürke: $\mathrm{Ti}$, kék: $\mathrm{Cl}$, piros: $\mathrm{O}$, sárga: $\mathrm{H})$ [14]

Az ALD-nek és a kémiai réteg leválasztásnak (chemical vapor deposition - CVD) számos hasonlósága van, de több ponton alapvetően különböznek, és ez teszi az ALD-t egyedivé. Az ALD-ben a reaktánsok adszorpciója a felületen önkorlátozott, és a különböző prekurzorok csak a hordozó felületén találkoznak és reagálnak el egymással, a gáztérben nem $[15,16]$.

Az ALD önkorlátozó növekedése eredményezi a módszer számos kiemelkedő előnyét. Az ALD-vel a filmvastagságot atomi szinten lehet szabályozni, mivel azt az ALD-ciklusok számával könnyen és pontosan lehet beállítani. Emellett az összetétel pontos szabályzására is lehetőség nyílik, és az ALD-vel könnyen megvalósítható a vékonyfilmek pontos 
adalékolása (dópolása), és nanorétegződések (nanolaminált szerkezetek) előállítása. Az ALD rendkívül egyenletes rétegek növesztését teszi lehetővé, és az illékony prekurzorok valamint az önkorlátozó növekedés miatt nagyon nagy mélység/szélesség arányú szerkezetek is egyenletesen bevonhatók. Az ALD esetén nem kell árnyék-hatással számolni, ami számos más fizikai vagy kémiai gázfázisú rétegnövesztési módszer hátránya, amelyeknél ha egy tárgy van a forrás és a célhordozó között, akkor ez jelentősen lecsökkentheti a tárgy mögött a filmnövekedés sebességét [17-21].

Az elmúlt évtizedekben az ALD-prekurzorkémia nagyon gyorsan fejlődött. Az ALD-reakciók során szilárd, folyadék vagy gáznemú prekurzorokat is lehet használni. Ha a szilárd vagy folyadék prekurzor parciális nyomása túl kicsi szobahőmérsékleten, hevíteni is lehet őket, hogy megfelelőek legyenek a szublimációs vagy párolgási körülmények. A prekurzorok lehetnek elemek, molekulák, gyökök. Mára már nagyon nagyszámú anyagot lehet ALD-vel növeszteni. ALD-vel lehetséges leválasztani elemeket ( $\mathrm{Au}, \mathrm{Ag}, \mathrm{Pt}, \mathrm{Ru}, \mathrm{Fe}$, stb.), binér vegyületeket (pl. oxidok, nitridek, karbidok, szulfidok, fluoridok, mint $\mathrm{Al}_{2} \mathrm{O}_{3}$, $\mathrm{TiO}_{2}, \mathrm{ZnO}, \mathrm{HfO}_{2}, \mathrm{GaN}, \mathrm{TaC}, \mathrm{CaS}, \mathrm{SrF}_{2}$, stb.), terner anyagokat (pl. $\mathrm{MgAl}_{2} \mathrm{O}_{4}$, TiAlN). Polimerek és szerves anyagok növesztése is elérhető ALD-vel. A molekuláris réteg leválasztással (molecular layer deposition - MLD), ami az ALD egy friss változata és ahol nem atomok, hanem molekula részletek kerülnek a filmbe rétegeként, az ALD-vel előállítható anyagok száma szinte korlátlanul növelhető szerves és szerves/szervetlen (pl. cinkonok, alukonok, stb.) anyagokkal [22-29].

Az ALD jellemző reakcióhőmérséklet tartománya 100-400 ${ }^{\circ} \mathrm{C}$ között van, és az ideális hőmérsékletzónát gyakran az úgynevezett ALD-ablakkal jellemzik. A magasabb hőmérséklet hasznos a prekurzorok és a szubsztrátum reaktivitása növelésének szempontjából, és a szorpciós folyamatok sebességét is növeli. Ugyanakkor túl magas hőmérséklet esetén a prekurzorok és a növesztett film bomlása következhet be. Alacsony hőmérsékleten a reaktivitás és a reakciók sebessége nem mindig kielégítő, és szennyezők is könnyebben maradnak a filmben. Mindent összevetve az ALD-reakciókat alacsonyabb és magasabb hőmérsékleten is el lehet végezni, mindig az adott alkalmazás számára kell optimalizálni a paramétereket. A hőmérséklet a film morfológiáját, kristályszerkezetét is alapvetően befolyásolja. Az alacsony hőmérsékletű (akár szobahőmérsékletű) ALD-reakciók lehetővé teszik hőérzékeny s szubsztrátumok (pl. polimerek, bioanyagok) bevonását [30-32].

Komoly erőfeszítések történnek, hogy a hagyományos termikus ALD lehetőségeit bővítsék és kiterjesszék az ipari alkalmazások számára. A plazma ALD során az egyik (általában nemfémes) prekurzor gyökös formában van jelen, és ezzel lehetővé vált $\mathrm{Ag}$ és $\mathrm{Au}$ filmek növesztése is. Az ALD-reakciók alapvetően vákuumban történnek, de kifejlesztették az atmoszférikus nyomású ALD-t is, ami nagyban megkönnyíti az ALD hozzáillesztését más ipari technológiai folyamatokhoz. Különösen a félvezető iparban fontos lehet, hogy a filmnövekedés ne a teljes szubsztrátumon, hanem csak egyes részein történjen, amit a területhatárolt (area selective) ALD-vel lehet elérni. Ugyancsak a félvezető iparban az ALD fordítottja, az atomi rétegü marás (atomic layer etching - ALE) is egyre fontosabb, aminek a reakciósémája megegyezik az ALD-vel, de ez esetben a rétegeket nem atomonként építik, hanem visszabontják [33]. Az ALD lassú reakciósebességét ellensúlyozni lehet nagyszámú hordozó egyszerre történő bevonásával, valamint a görgőszalagszerü (roll-to-roll) vagy térben elválasztott (spatial) ALD technológiákkal [34-37]. Egyre fontosabbá válik porok bevonása is ALD-vel, amit fluidizációs vagy forgatott ALD reaktorokban lehet megtenni, illetve speciális (pl. porózus falú) mintatartók segítségével [38].

\section{Az ALD alkalmazása a nanotechnológiában}

Az ALD lehetővé teszi egyenletes filmek növesztését háromdimenziós (3D) hordozókon úgy, hogy a filmvastagságot nanométeresnél is precízebben lehet szabályozni. Ezzel az ALD új stratégiákat nyújt nanoméretü anyagok tulajdonságainak módosításához, és új szintézis utakat nyit meg nanoszerkezetü anyagok előállításához.

Mára kiemelkedő eredmények születtek az ALD nanotechnológiai alkalmazása kapcsán, többek között nanoszemcsék, nanocsövek, nanoszálak, nanolaminátumok, pórusos nanoszerkezetű anyagok, inverz opál szerkezetek, nanokompozitok, bionanoanyagok elöállítása és bevonása terén. [39-43]. Az ALD nanotechnológiai alkalmazásával kapcsolatos tanulmányok száma exponenciális nő. Ezt jól mutatja, hogy az ALD-vel elöállított addigi összes nanoszerkezetet bemutató összefoglaló közlemény utoljára 2009-ben jelent meg [44]. Azóta viszont olyan mértékü volt a kutatás a területen, hogy lehetetlen volt az eredményeket egy cikkben összefoglalni. Így ezt követően az ALD nanotechnológiai felhasználásáról már elsősorban az egyes részterületeken születtek összefoglaló cikkek, pl. katalízis [45], energiatároló rendszerek [46,47], gázszenzorok [48], fotovoltaikus [49] és fotokatalitikus [50] alkalmazások stb. témakörben.

\section{ALD-vel előállított nanoszerkezetű anyagok a BME Szervetlen és Analitikai Kémia Tanszéken}

A ma világszinten használt ALD-technológia alapja Finnországból, Helsinkiből származik. A Budapesti Műszaki és Gazdaságtudományi Egyetem (BME), Szervetlen és Analitikai Kémia Tanszéknek több évtizedes együttmüködése van a Helsinkiben lévő Aalto University-vel (korábban Helsinki University of Technology - TKK) és a University of Helsinkivel. Az első intézményben dr. Lauri Niinistö vezette hosszú ideig a Szervetlen Kémiai Laboratóriumot, a University of Helsinkin pedig dr. Markku Leskelä az ugyancsak Szervetlen Kémiai Laboratórium vezetője évtizedek óta. Mindkét laboratórium világszinten is vezető az ALD kutatás területén. A BME Szervetlen és Analitikai Kémia Tanszék részéről előbb dr. Liptay György, majd dr. Pokol György és dr. Madarász János, végül dr. Szilágyi Imre Miklós vettek részt a közös munkában. 
Kezdetben az együttmúködés szervetlen és fémorganikus anyagok előállítására, jellemzésére, termoanalitikai mérésére koncentrálódott, ahol külön figyelmet kaptak az ALD-reakciók során használt prekurzorok vizsgálatai. Később már közvetlenül ALD-reakciók terén is több közös munka született, pl. alacsony oxidációs állapotú volfrámot tartalmazó volfrám-oxid filmek ALD-reakciójának kidolgozása [51].

Az együttmüködés során intenzív kutatócsere folyt a finn és magyar intézmények között. Az együttmüködés mélységét jelzi, hogy dr. Lauri Niinistö a BME díszdoktora lett, valamint a Magyar Kémikusok Egyesülete (MTA) Fabinyi Rudolf díját is megkapta. 2010-2012 között dr. Szilágyi Imre Miklós a University of Helsinkin komplex nanostruktúrákat állított elő ALD-vel, és onnan visszatérve kezdett egy új kutatócsoport kialakításába a BME Szervetlen és Analitikai Kémia Tanszéken és az MTA-BME Müszaki Analitikai Kémiai Kutatócsoportban.

A BME Szervetlen és Analitikai Kémia Tanszéken az ALD-vel kapcsolatos kutatómunka fö fókusza funkcionális nanoszerkezetű anyagok előállítása. Szubsztrátumként oxid (pl. $\mathrm{WO}_{3}, \mathrm{TiO}_{2}, \mathrm{ZnO}$, stb.) nanoszemcséket, nanoszálakat, nanolemezeket, polimer (pl. poli(vinil-pirrolidon) - PVP, poli(vinil-alkohol) - PVA, poli(metil-metakrilát) - PMMA) nanoszálakat és nanoszemcséket, valamint szén nanoszerkezetű anyagokat (pl. fullerén, grafén-oxid, szén nanocső, szén aerogél, szén nanogömb) használnak. Ezeket változatos módszerekkel állítják elő, pl. termikus bontás, szol-gél, hidrotermális és elektrosztatikus szálhúzás eljárásokkal. A hordozókra döntően oxid $\left(\mathrm{TiO}_{2}, \mathrm{ZnO}\right.$, $\mathrm{Al}_{2} \mathrm{O}_{3}$ ) filmeket visznek fel ALD-vel, és így mag/héj nanoszemcséket és nanoszálakat, porózus nanoszerkezetü anyagokat, nanocsöveket, nanokompozitokat stb. nyernek.

A kutatás célja az, hogy felderítsék a szubsztrátum és az ALD-film kölcsönhatását, és tanulmányozzák, hogyan lehet optimalizálni a nanorendszerek tulajdonságait (szubsztrátum összetétele, kristályszerkezete, morfológiája, valamint az ALD-film összetétele, vastagsága, szerkezete) az egyes alkalmazások számára. Eddig a nanokompozitok fotokatalitikus és gázszenzor alkalmazása terén született a legtöbb eredmény, de számos további területen is aktívak (pl. öntisztító bevonatok, katalízis, elektrokróm filmek, fotovoltaikus rendszerek, stb.).

$\mathrm{Az}$ alábbiakban a teljesség igénye nélkül néhány fontosabb eredményüket soroljuk fel. Ezek egy része már megjelent cikkekben, más része publikálás alatt van. Először az általuk előállított fotokatalitikus nanoszerkezetü anyagok közül ismertetünk néhány példát. Egy új, teljesen vizes alapú eljárást dolgoztak ki monoklin (m-) $\mathrm{WO}_{3}$ nanoszálak előállítására elektrosztatikus szálhúzással, és $\mathrm{TiO}_{2}$ nanofilmekkel vonták be őket ALD-vel (2. ábra). A mag/héj $\mathrm{WO}_{3} / \mathrm{TiO}_{2}$ kompozit nanoszálak látható fényben aktív fotokatalizátorok voltak, és a $\mathrm{TiO}_{2}$ filmvastagság változtatásával szabályozni lehetett a fotokatalitikus teljesítményt [52-53]. Elektrosztatikus szálhúzással $\mathrm{ZnO}$ és $\mathrm{TiO}_{2}$ nanoszálakat is elöállítottak, amelyeket $\mathrm{ALD} \mathrm{TiO}_{2}$ és $\mathrm{ZnO}$ rétegekkel vontak be. A mag/héj $\mathrm{ZnO} / \mathrm{TiO}_{2}$ és $\mathrm{TiO}_{2} / \mathrm{ZnO}$ kompozit nanoszálakat fotokatalízis alkalmazásokban vizsgálták [54]. Fontos eredmény volt, hogy kimutatták, hogy nem minden esetben javít az ALD-filmmel való bevonás a hordozó tulajdonságain. Az elektrosztatikus szálhúzással előállított oxid nanoszálak jellemzően kis oxid nanoszemcsékből állnak össze. Ha a szálra növesztett ALD-film túl vastag, akkor eltömi a szemcsék közötti réseket, csökkenti a fajlagos felületet, és ezzel romolhat a kompozit teljesítménye az adott alkalmazásban. Ez fontos információ, mert az ALD-filmek esetleges hátrányát kevesen vizsgálták. A fentiek mellett $\mathrm{TiO}_{2}$ és $\mathrm{ZnO}$ nanocsöveket is készítettek úgy, hogy elektrosztatikus szálhúzással előállított PVA és PVP szálakat oxid ALD-filmmel vontak be, majd eltávolították a polimer magot hevítéssel vagy oldással. Az így kapott oxid nanocsövek fotokatalitikus hatékonysága elérte a fotokatalízisben általában referenciaként használt $\mathrm{P} 25 \mathrm{TiO}_{2}$-ét.
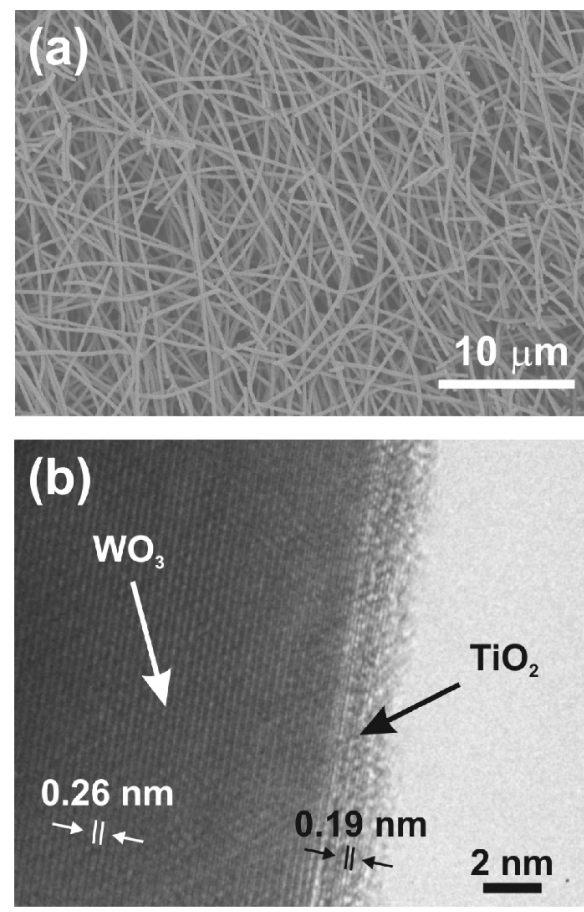

2. Ábra. (a) Elektrosztatikus szálhúzással előállított $\mathrm{WO}_{3}$ nanoszálak SEM felvétele; (b) $\mathrm{WO}_{3} / 1.5 \mathrm{~nm} \mathrm{TiO}_{2}$ mag/héj kompozit nanoszálak HRTEM felvétele [53]. (Copyright Wiley-VCH Verlag GmbH \& Co. $\mathrm{KGaA}$. Reproduced with permission.)

Mikrohullámú hidrotermális szintézissel hexagonális (h-) $\mathrm{WO}_{3}$ nanoszálakat készítettek, amikre $\mathrm{TiO}_{2}$-ot növesztettek ALD-vel, és a kompozitot fotokatalizátorként használták. Kimutatták, hogy míg az ALD-vel növesztett $\mathrm{TiO}_{2}$ nanoszemcséket képez a h- $\mathrm{WO}_{3}$ nanoszálakon, az m- $\mathrm{WO}_{3}$ felületén egyenletes film formájában nő [55]. Ez azt jelenti, hogy a $\mathrm{WO}_{3}$ eltérö módosulatain máshogy történik az ALD-nukleáció, ami úttörő eredmény. $\mathrm{A} \quad \mathrm{WO}_{3}$ két módosulatának eltérő az összetétele. Míg az m- $\mathrm{WO}_{3}$ teljesen oxidált, addig a h- $\mathrm{WO}_{3}$ kis mennyiségü szennyező kationokat tartalmaz a csatornás szerkezetében, amik a metastabil hexagonális szerkezet stabilizáláshoz szükségesek. Emiatt a $\mathrm{h}-\mathrm{WO}_{3}$-ban a volfrám atomok egy része részlegesen redukált. Ez kihat arra is, hogy a felszínén kisebb az -OH csoportok sürüsége, mint az $\mathrm{m}-\mathrm{WO}_{3}$ esetében [56-57], ami kevesebb nukleációs helyet jelent az ALD-reakció során, és emiatt a $\mathrm{TiO}_{2}$ csak szemcsékként növekszik, és nem egyenletes filmként. 
Elsőként növesztettek ALD-filmet $\left(\mathrm{TiO}_{2}\right)$ lágy biológiai szövetre (a lótuszlevél nanostrukturált felületére), és így egy szuperhidrofób és fotokatalitikus bionanokompozitot kaptak [58]. Az ALD-reakciót alacsony hőmérsékleten $\left(65^{\circ} \mathrm{C}\right)$ végezték, és ekkor a lótusz víztaszító hatását okozó mikroméretű dombokat és a rajtuk lévő 50-100 nm átmérőjü nanocsöveket is sikerült megőrizni. A $\mathrm{TiO}_{2}$ vastagságának változtatásával szabályozni tudták a nedvesítési és fotokatalitikus tulajdonságokat. Az alacsony ALD-reakcióhőmérséklet miatt a $\mathrm{TiO}_{2}$ amorf formában nőtt, de újdonságként mégis tapasztaltak fotokatalitikus hatást.

Az ALD-vel növesztett amorf $\mathrm{TiO}_{2}$ fotokatalitikus hatását további hordozókon is vizsgálták. $\mathrm{A} \mathrm{TiO}_{2}$ szerkezetét (amorf vagy kristályos) az ALD-reakcióhőmérsékletével lehet szabályozni. Kb. $200{ }^{\circ} \mathrm{C}$ alatt amorf formában nő a $\mathrm{TiO}_{2}$, felette pedig anatázként (még magasabb hőmérsékleten rutil és brookit $\mathrm{TiO}_{2}$ előállításáról is beszámoltak korábban mások) [22]. Ennek megfelelőn amorf és anatáz $\mathrm{TiO}_{2}-\mathrm{t}$ növesztettek $\mathrm{SiO}_{2}$ (3. ábra) és PMMA nanoszemcsékre, és bár az ALD-vel elóállított amorf $\mathrm{TiO}_{2}$-nak jóval kisebb volt a fotokatalitikus hatása, mint a kristályosnak, de egyértelmüen kimutatható volt. Ez meglepő eredmény, mivel korábban széleskörüen a $\mathrm{TiO}_{2}$-t csak kristályos formában tartották fotokatalitikusan aktívnak, amorf formában nem [59]. Azonban a kísérletek azt mutatják, hogy az ALD-vel növesztett amorf $\mathrm{TiO}_{2}$-nak van fotokatalitikus hatása, aminek pontos forrása egyelöre még nem tisztázott; szóba jöhetnek pl. a $\mathrm{TiO}_{2}$-ban lévő szennyezők (pl. C), kristályos nanodomének a makroszkopikusan amorf $\mathrm{TiO}_{2}$-ben, a szubsztrátum és az amorf $\mathrm{TiO}_{2}$ kölcsönhatása.

3. Ábra. Szol-gél $\mathrm{SiO}_{2}$ szemcse TEM felvétele, melyre 20-30 nm amorf $\mathrm{TiO}_{2}$-réteg lett ALD-vel növesztve

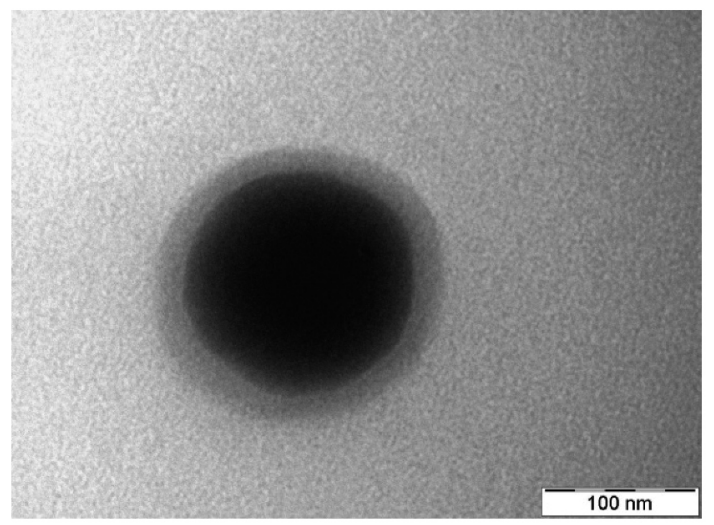

Amorf $\mathrm{TiO}_{2}$-t számos szén nanoszerkezetre is leválasztottak ALD-vel, és ezek a kompozitok is mutattak fotokatalitikus hatást. Többek között -OH csoportokkal funkcionalizált fullerénre (fullerol) 1-2 nm TiO 2 szemcséket növesztettek (4. ábra). Ez volt az első tanulmány, ahol sikerült egyedi fullerén molekulára bármilyen ALD réteget növeszteni [60]. Grafén-oxidra és szén aerogélre is leválasztottak amorf $\mathrm{TiO}_{2}$-ot, valamint szén nanogömbökre. Ez utóbbi esetben a szén mag hevítéssel történő eltávolítása után üreges $\mathrm{TiO}_{2}$ nanogömböket kaptak [61,62]. A fenti $\mathrm{SiO}_{2}$ és szén nanoszerkezet rendszerek esetén a $\mathrm{TiO}_{2}$ mellett referenciaként fotokatalitikusan aktív $\mathrm{ZnO}$ és nem aktív $\mathrm{Al}_{2} \mathrm{O}_{3}$ rétegeket is növesztettek.
Fotokatalízis mellett gázszenzor alkalmazásban is vizsgáltak ALD-vel előállított nanoszerkezetü anyagokat. Felderítették a korábban említett, elektrosztatikus szálhúzással és ALD-vel szintetizált mag/héj $\mathrm{ZnO} / \mathrm{TiO}_{2}, \mathrm{TiO}_{2} / \mathrm{ZnO}$ [54] valamint $\mathrm{WO}_{3} / \mathrm{TiO}_{2}$ kompozit nanoszálak gázérzékelö tulajdonságait is. Hevítéssel m- és $\mathrm{h}-\mathrm{WO}_{3}$ nanoszemcséket készítettek, és ezekre $\mathrm{ZnO}$ és $\mathrm{Al}_{2} \mathrm{O}_{3}$ rétegeket választottak le, majd gázszenzorként tesztelték a kompozitokat. Szén nanocsövekre (carbon nanotube - CNT) $\mathrm{TiO}_{2}$ és $\mathrm{ZnO}$ rétegeket növesztettek több rétegben, és megmérték, hogyan befolyásolja a gázérzékelést az oxid rétegek fajtája és sorrendje a $\mathrm{CNT} / \mathrm{TiO}_{2}, \mathrm{CNT} / \mathrm{ZnO}, \mathrm{CNT} / \mathrm{TiO}_{2} / \mathrm{ZnO}$, $\mathrm{CNT} / \mathrm{ZnO} / \mathrm{TiO}_{2} \mathrm{mag} /$ héj nanocsövek esetén.

Azt is tanulmányozták, hogy ultravékony oxid filmeknek önmagukban van-e gázérzékelő tulajdonsága. Kimutatták, hogy már nagyon vékony (10-20 nm) ALD-vel növesztett $\mathrm{ZnO}$ és $\mathrm{TiO}_{2}$ oxid rétegeknek is jó érzékenysége van kvarc kristály mikromérleg (quartz crystal microbalance - QCM) gázszenzorokban $[63,64]$.

Az ALD mellett referenciaként más módszerekkel is, pl. CVD, MAPLE (matrix assisted pulsed laser evaporation), PLD (pulsed laser deposition) és ún. forgótárcsás eljárás (spin coating) készítettek oxid nanofilmeket, amiket elsősorban gázszenzorként és elektrokróm alkalmazásban vizsgáltak [65-69].

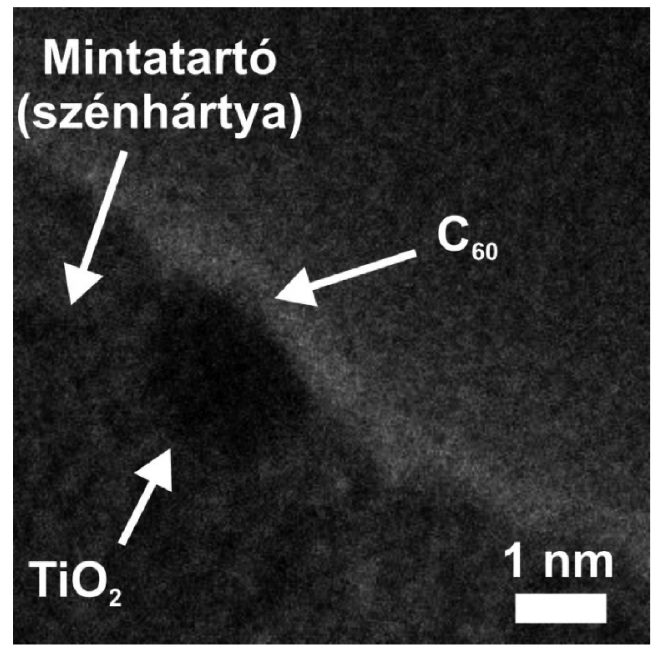

4. Ábra. $\mathrm{OH}$-funkcionalizált $\mathrm{C}_{60}$ molekulára $\mathrm{ALD}$-vel növesztett $\mathrm{TiO}_{2}$ nanoszemcse TEM felvétele [60] (doi: 10.1088/0957-4484/24/24/245701. (C) IOP Publishing. Reproduced with permission. All rights reserved.)

További alkalmazásokban is használtak ALD-vel előállított nanoszerkezetü anyagokat. Például egy pórusos, ion mart polimer Kapton membránra $\mathrm{TiO}_{2}$ és $\mathrm{ZnO}$ réteget növesztettek ALD-vel, és a kompozit membránt rugalmas MCP (microchannel plate) elektron detektorként tesztelték [70]. ALD réteg növesztésével kimutatták, hogy a madártollak felszínén lévő nanostruktúrák szerkezeti színt okozhatnak; szajkó kék tollán fedeztek fel 100-200 nm hosszanti nanobarázdákat, amik hozzájárulnak a toll színéhez.

Az ALD nanotechnológiai alkalmazását az adott eredményeket leíró szakcikkek mellett két összefoglaló közleményben is tárgyalták [71,72]. 


\section{Összefoglalás}

$\mathrm{Az}$ atomi réteg leválasztás egy gázfázisú vékonyfilm növesztési módszer, mely egyediségét az adja, hogy vele atomi szinten szabályozott vastagsággal és összetétellel lehet egyenletes rétegeket növeszteni erösen strukturált $3 \mathrm{D}$ hordozókra is. Az ALD-t már több mint egy évtizede széleskörüen alkalmazzák a félvezető iparban, de mellette számos más területen is egyre inkább előtérbe kerül.

A BME Szervetlen és Analitikai Kémia Tanszéken az ALD-vel kapcsolatos kutatás komplex, funkcionális nanoszerkezetủ anyagok programozott előállítására irányul. Elsősorban oxid nanofilmeket és nanoszemcséket növesztenek ALD-vel oxid, polimer és szén nanoszerkezetekre. A céljuk az, hogy a hordozó és különösen az ALD réteg paramétereinek pontos beállításával a nanorendszerek tulajdonságait az adott alkalmazás (pl. fotokatalízis, gázérzékelés) számára tervszerüen szabályozzák és optimalizálják, valamint teljesen új, egyedi, kiemelkedő tulajdonságú nanorendszereket állítsanak elő.

\section{Hivatkozások}

1. Ritala, M.; Leskelä, M In Handbook of Thin Films Chapter 2 - Atomic layer deposition, Academic Press, 2002 https://doi.org/10.1016/B978-012512908-4/50005-9

2. Ahvenniemi, E.; et al, J. Vac. Sci. Technol. A. 2017, 35, 010801. https://doi.org/10.1116/1.4971389

3. Johnson, R. W.; Hultqvist, A.; Bent, S. F. Mater. Today 2014, 17, 236.

https://doi.org/10.1016/j.mattod.2014.04.026

4. Parsons, G. N.; George, S. M.; Knez, M. MRS Bull. 2011, 36, 865. https://doi.org/10.1557/mrs.2011.238

5. Niinisto, L.; Paivasaari, J.; Niinisto, J.; Putkonen, M.; Nieminen, M. Phys. Status Solidi A 2004, 201, 1443. https://doi.org/10.1002/pssa.200406798

6. Hwang, C. S. Atomic Layer Deposition for Semiconductor: Springer: New York, Heidelberg, Dordrecht, London, 2014. https://doi.org/10.1007/978-1-4614-8054-9

7. Pinna, N.; Knez, M. Atomic Layer Deposition of Nanostructured Materials Wiley-VCH Verlag \& Co. KGaA: Weinheim, Germany, 2011. https://doi.org/10.1002/9783527639915

8. Robertson, J. Eur. Phys. J.-Appl. Phys. 2004, 28, 265. https://doi.org/10.1051/epjap:2004206

9. Leskelä, M.; Ritala, M. J. Solid State Chem. 2003, 171, 170. https://doi.org/10.1016/S0022-4596(02)00204-9

10. George, S. M. Chem. Rev. 2009, 110, 111. https://doi.org/10.1021/cr900056b

11. Puurunen, R. L. J. Appl. Phys. 2005, 97, 121301. https://doi.org/10.1063/1.1940727

12. Zaera, F. Coordin. Chem. Rev. 2013, 257, 3177. https://doi.org/10.1016/j.ccr.2013.04.006

13. Putkonen, M.; Sajavaara, T.; Niinisto, L.; Keinonen, J. Anal. Bioanal. Chem. 2005, 382, 1791. https://doi.org/10.1007/s00216-005-3365-3

14. Barron, Andrew. R. Atomic Layer Deposition. OpenStax-CNX module: m25737, http://cnx.org/contents/rimBK1xx@2/Atomic-Layer-Deposi tion (21 June 2017)

15. Devi, A. Coordin. Chem. Rev. 2013, 257, 3332. https://doi.org/10.1016/j.ccr.2013.07.025

\section{Köszönetnyilvánítás}

A szerző köszönetét fejezi ki a kutatócsoportja tagjainak, valamint a tanszék munkatársainak. Köszönetet nyilvánít az MTA-EK-MFA és a Debreceni Egyetem Szilárdtest Fizikai Tanszék munkatársainak az ALD-kutatás terén való együttmüködésért, és a nanoszerkezetü anyagok előállításában és jellemzésében részt vevő további intézményeknek és partnereknek is. Köszönetet mond az anyagi támogatásért: NKFI K 124212, NKFI TNN_16 123631, OTKA-PD 109129, Bolyai János Kutatási Ösztöndíj (2011-2014, 2015-2018), Marie Curie Intra-European Fellowship (Nr. 235655). A VEKOP-2.3.2-16-2017-00013 projekt keretében folyó kutatásokat az Európai Unió és Magyarország Kormánya támogatta az Európai Regionális Fejlesztési Alap hozzájárulásával. Az Emberi Erőforrások Minisztériuma ÚNKP-17-4-IV kódszámú Új Nemzeti Kiválóság Programjának támogatásával készült.

16. Emslie, D. J. H.; Chadha, P.; Price, J. S. Coordin. Chem. Rev. 2013, 257, 3282. https://doi.org/10.1016/j.ccr.2013.07.010

17. Suntola, T. Appl. Surf. Sci. 1996, 100, 391. https://doi.org/10.1016/0169-4332(96)00306-6

18. Niinisto, L.; Ritala, M.; Leskela, M.; Mat. Sci. Eng. B 1996, 41, 23. https://doi.org/10.1016/S0921-5107(96)01617-0

19. Elers, K. E.; Blomberg, T.; Peussa, M.; Aitchison, B.; Haukka, S.; Marcus, S. Chem. Vapor. Dep. 2006, 12, 13. https://doi.org/10.1002/cvde.200500024

20. Ritala, M. Appl. Surf. Sci. 1997, 112, 223. https://doi.org/10.1016/S0169-4332(96)01004-5

21. Ritala, M.; Leskelä, M. Nanotechnology 1999, 10, 19. https://doi.org/10.1088/0957-4484/10/1/005

22. Miikkulainen, V.; Leskela, M.; Ritala, M.; Puurunen, R. L. J. Appl. Phys. 2013, 113, 021301. https://doi.org/10.1063/1.4757907

23. Lee, S. W.; Choi, B. J.; Eom, T.; Han, J. H.; Kim, S. K.; Song, S. J.; Lee, W.; Hwang, C. S. Coordin. Chem. Rev. 2013, 257, 3154. https://doi.org/10.1016/j.ccr.2013.04.010

24. Sundberg, P.; Karppinen, M. Beilstein. J. Nanotechn. 2014, 5, 1104. https://doi.org/10.3762/bjnano.5.123

25. Hatanpää. T.; Ritala, M.; Leskelä, M. Coordin. Chem. Rev. 2013, 257, 3297. https://doi.org/10.1016/j.ccr.2013.07.002

26. Knisley, T. J.; Kalutarage, L. C.; Winter, C. H. Coordin. Chem. Rev. 2013, 257, 3222.

https://doi.org/10.1016/j.ccr.2013.03.019

27. Ramos, K. B.; Saly, M. J.; Chabal, Y. J. Coordin. Chem. Rev. 2013, 257, 3271. https://doi.org/10.1016/j.ccr.2013.03.028

28. Tynell, T.; Karppinen, M. Semicond. Sci. Tech. 2014, 29 , 043001. https://doi.org/10.1088/0268-1242/29/4/043001

29. Putkonen, M; Niinistö, L. Organometallic Precursors for Atomic Layer Deposition in Precursor Chemistry of Advanced Materials Springer: Berlin Heidelberg, 125 p. 2005. https://doi.org/10.1007/b136145

30. Parsons, G. N.; Atanasov, S. E.; Dandley, E. C.; Devine, C. K.; Gong, B.; Jur, J. S.; Lee, K.; Oldham, C. J.; Peng, Q.; Spagnola, J. C.; Williams, P. S. Coordin. Chem. Rev. 2013, 257, 3323. https://doi.org/10.1016/j.ccr.2013.07.001 
31. Ponraj, J. S.; Attolini, G.; Bosi, M. Crit. Rev. Solid State 2013, 38, 203.

https://doi.org/10.1080/10408436.2012.736886

32. Kim, H. J. Vac. Sci. Technol. B 2003, 21, 2231

https://doi.org/10.1116/1.1622676

33. Kanarik, K. J.; L.Thorsten,; Hudson, E. A.; Sriraman, S.; Tan, S.; Marks, J.; Vahedi, V.; Gottscho, R. A. J. Vac. Sci. Technol. A 2015, 33, 020802 . https://doi.org/10.1116/1.4913379

34. Knoops, H. C. M.; Langereis, E.; van de Sanden, M. C. M.; Kessels, W. M. M. J. Electrochem. Soc. 2010, 157, G241. https://doi.org/10.1149/1.3491381

35. Potts, S. E.; Kessels, W. M. M. Coordin. Chem. Rev. 2013, 257, 3254. https://doi.org/10.1016/j.ccr.2013.06.015

36. Mackus, A. J. M.; Bol, A. A.; Kessels, W. M. M. Nanoscale 2014, 6, 10941. https://doi.org/10.1039/C4NR01954G

37. Leskelä, M.; Ritala, M. Thin Solid Films 2002, 409, 138. https://doi.org/10.1016/S0040-6090(02)00117-7

38. Longrie, D.; Deduytsche, D.; Detavernier, C. J. Vac. Sci. Technol. A 2015, 32, 010802. https://doi.org/10.1116/1.4851676

39. Knez, M.; Nielsch, K.; Niinistö, L. Adv. Mater. 2007, 19, 3425. https://doi.org/10.1002/adma.200700079

40. Detavernier, C.; Dendooven, J.; Sree, S. P.; Ludwig, K. F.; Martens, J. A.; Chem. Soc. Rev. 2011, 40, 5242. https://doi.org/10.1039/c1cs15091j

41. Liu, M. N.; Li, X. L.; Karuturi, S. K.; Tok, A. I. Y.; Fan, H. J. Nanoscale 2012, 4, 1522. https://doi.org/10.1039/c2nr11875k

42. Bakke, J. R.; Pickrahn, K. L.; Brennan, T. P.; Bent, S. F.; Nanoscale 2011, 3, 3482 . https://doi.org/10.1039/c1nr10349k

43. Marichy, C.; Pinna, N. Coordin. Chem. Rev. 2013, 257, 3232. https://doi.org/10.1016/j.ccr.2013.08.007

44. Kim, H.; Lee, H. B. R.; Maeng, W. J. Thin Solid Films 2009, 517, 2563, https://doi.org/10.1016/j.tsf.2008.09.007

45. O’Neill, B. J.; Jackson, D. H. K.; Lee, J.; Canlas, C.; Stair, P. C.; Marshall, C. L.; Elam, J. W.; Kuech, T. F.; Dumesic, J. A.; Huber, G. W. ACS Catal. 2015, 5, 1804. https://doi.org/10.1021/cs501862h

46. Meng, X. J. Mater. Chem. A 2017, 5, 10127. https://doi.org/10.1039/C7TA02742G

47. Ahmed, B.; Xia, C.; Alshareef, H. N. Nano Today 2016, 11, 250. https://doi.org/10.1016/j.nantod.2016.04.004

48. Marichy, C.; Pinna, N. Adv. Mater. Interfac. 2017, 4, 1600758. https://doi.org/10.1002/admi.201600335

49. Deng, K.; Li, L. Adv. Mater. Interfac. 2016, 3, 1600505. https://doi.org/10.1002/admi.201600505

50. Wang, T.; Luo, Z.; Li C.; Gong, J. Chem. Soc. Rev. 2014, 43, 7469. https://doi.org/10.1039/C3CS60370A

51. Dezelah IV, C. L.; El-Kadri, O. M.; Szilágyi, I. M.; Campbell, J.M.; Arstila, K.; Niinistö, L.; Winter, C.H. J. Am. Chem. Soc. 2006, 128, 9638. https://doi.org/10.1021/ja063272w

52. Szilágyi, I. M.; Santala, E.; Heikkilä, M.; Kemell, M.; Nikitin, T.; Khriachtchev, L.; Räsänen, M.; Ritala, M.; Leskelä. M. J. Therm. Anal. Calorim. 2011, 105, 73. https://doi.org/10.1007/s10973-011-1631-5

53. Szilágyi, I. M.; Teucher, G.; Firkala, T.; Santala, E.; Pore, V.; Nikitin, T.; Khriachtchev, L.; Räsänen, M.; Ritala, M.; Leskelä, M. Chem. Vapor Dep. 2013, 19, 149. https://doi.org/10.1002/cvde.201207037

54. Boyadjiev, S. I.; Kéri, O.; Bárdos, P.; Firkala, T.; Gáber, F.; Nagy, Z. K.; Baji, Z.; Takács, M.; Szilágyi, I. M. Appl. Sur. Sci. 2017, in press, https://doi.org/10.1016/j.apsusc.2017.03.030
55. Nagy, D.; Firkala, T.; Drotár, E.; Szegedi, Á.; László, K.; Szilágyi, I. M. RSC Adv. 2016, 6, 95369. https://doi.org/10.1039/C6RA18899K

56. Szilágyi, I. M.; Madarász, J.; Pokol, G.; Király, P.; Tárkányi, G.; Saukko, S.; Mizsei, J.; Tóth, A. L.; Szabó, A.; Varga-Josepovits, K. Chem. Mater. 2008, 20, 4116. https://doi.org/10.1021/cm800668x

57. Szilágyi, I. M.; Fórizs, B.; Rosseler, O.; Szegedi, Á.; Németh, P.; Király, P.; Tárkányi, G.; Vajna, B.; Varga-Josepovits, K.; László, K.; Tóth, A. L.; Baranyai, P.; Leskelä, M. J. Catal. 2012, 294, 119. https://doi.org/10.1016/j.jcat.2012.07.013

58. Szilágyi, I. M.; Teucher, G.; Härkönen, E.; Färm, E.; Hatanpää, T.; Nikitin, T.; Khriachtchev, L.; Räsänen, M.; Ritala, M.; Leskelä, M. Nanotechnology 2013, 24, 245701. https://doi.org/10.1088/0957-4484/24/24/245701

59. Huang, J.; Liu, Y.; Lu, L.; Li, L. Res. Chem. Intermed. 2011, 38, 487. https://doi.org/10.1007/s11164-011-0365-0

60. Justh, N.; Firkala, T.; László, K.; Lábár, J.; Szilágyi, I. M. Appl. Surf. Sci. 2017, 419, 497.

https://doi.org/10.1016/j.apsusc.2017.04.243

61. Bakos, L. P.; Justh, N.; Hernádi, K.; Kiss, G.; Réti, B.; Erdélyi, Z.; Parditka, B.; Szilágyi. I.M.; J. Phys. Conf. Ser. 2016, 764, 012005. https://doi.org/10.1088/1742-6596/764/1/012005

62. Justh, N. Bakos, L. P.; Hernádi, K.; Kiss, G.; Réti, B.; Erdélyi, Z.; Parditka, B.; Szilágyi, I. M. Sci. Rep. 2017, in press, https://doi.org/10.1038/s41598-017-04090-0

63. Boyadjiev, S.; Georgieva, V.; Vergov, L.; Baji, Z.; Gáber, F.; Szilágyi, I. M. J. Phys. Conf. Ser. 2014, 559, 012013. https://doi.org/10.1088/1742-6596/559/1/012013

64. Boyadjiev, S.; Georgieva, V.; Yordanov, R.; Raicheva, Z.; Szilágyi, I. M. Appl. Surf. Sci. 2016, 387, 1230. https://doi.org/10.1016/j.apsusc.2016.06.007

65. Gesheva, K.; Arvizu, M.; Bodurov, G.; Ivanova, T.; Niklasson, G.; Iliev, M.; Vlakhov, T.; Terzijska, P.; Popkirov, G.; Boyadjiev, S.; Jágerszki, G.; Szilágyi, I. M.; Marinov, Y. J. Phys. Conf. Ser. 2016, 764, 012010. https://doi.org/10.1088/1742-6596/764/1/012010

66. Boyadjiev, S. I.; Stefan, N.; Szilágyi, I. M.; Mihailescu, N.; Visan, A.; Mihailescu, I. N.; Stan, G. E.; Besleaga, C.; Iliev, M. T.; Gesheva, K. A.; J. Phys. Conf. Ser. 2017, 780, 012013. https://doi.org/10.1088/1742-6596/780/1/012013

67. Boyadjiev, S. I.; Georgieva, V.; Stefan, N.; Stan, G. E.; Miroiu, F. M.; Mihailescu, N.; Visan, A.; Mihailescu, I. N.; Besleaga, C.; Szilágyi, I. M. Appl. Surf. Sci. 2017, 417, 218. https://doi.org/10.1016/j.apsusc.2017.03.212

68. Boyadjiev, S.; Manduca, B.; Szücs, J.; Szilágyi, I. M. J. Phys. Conf. Ser. 2016, 700, 012019. https://doi.org/10.1088/1742-6596/700/1/012019

69. Boyadjiev, S.; dos Lopes Santos, G.; Szücs, J.; Szilágyi, I. M. J. Phys. Conf. Ser. 2016, 1722, 140004. https://doi.org/10.1063/1.4944194

70. Mättö, L.; Szilágyi, I. M.; Laitinen, M.; Ritala, M.; Leskelä, M. Nucl. Instr. Method. Phys. Res. A 2016, 832, 254. https://doi.org/10.1016/j.nima.2016.06.132

71. Gesheva, K.; Ivanova, T.; Bodurov, G.; Szilágyi, I. M.; Justh, N.; Kéri, O.; Bojadjiev, S.; Nagy, D.; Aleksandrova. M. J. Phys. Conf. Ser. 2016, 682, 012011. https://doi.org/10.1088/1742-6596/682/1/012011

72. Szilágyi, I. M.; Nagy, D. J. Phys. Conf. Ser. 2014, 559, 012010. https://doi.org/10.1088/1742-6596/559/1/012010

124. évfolyam, 3. szám, 2018. 


\section{Atomic layer deposition in nanotechnology}

Atomic layer deposition (ALD) is a thin film deposition technique, based on successive, alternative surface controlled reactions from the gas phase. ALD was already invented in St. Petersburg, Russia in the 1950-1960s and in the 1970s in Helsinki, Finland, independent of each other. However, the real international interest about ALD has arrived only in the 1990s, when ALD was considered to be a key future method in the semiconductor industry.

A general ALD reaction has four consecutive steps (Fig. 1): (i) the first precursor is pulsed into the reactor, which chemisorbs on the surface of the substrate; (ii) the unreacted precursor or reaction byproducts are removed by an inert gas purge and/or by evacuation; (iii) the second precursor is purged, which reacts with the first precursor solely on the surface; (iv) the unused second precursor and the reaction byproducts are removed.

The uniqueness of ALD is based on that in ALD the adsorption of reactants is self-limited and the various precursors meet only on the surface of the substrate. The self-limiting growth leads to the many advantages of ALD. ALD can provide thickness control at an atomic level, as the film thickness can be programmed easily by the number of the ALD cycles. Not only the thickness, but also the composition of the film can be controlled precisely.

ALD can use solid, liquid or gaseous precursors. The precursors can be elements, molecules, radicals. ALD can be used to deposit elements, binary and ternary compounds, as well as polymers and organic materials. Molecular layer deposition (MLD), a recent version of ALD, where a molecular fragment is deposited during each ALD cycle, can increase the number of ALD prepared materials even further with organic or organic/inorganic (e.g. zincones, alucones) polymers. The usual reaction temperature is between $100-400{ }^{\circ} \mathrm{C}$, and the ideal reaction temperature zone is often described by the so-called ALD window. However, ALD reactions can be performed at both higher and lower temperatures as well.

Considerable efforts have been made to extend the possibilities of traditional ALD to meet the industrial requirements. Plasma or radical enhanced ALD made it possible to deposit $\mathrm{Ag}$ or $\mathrm{Au}$, which were not possible by thermal ALD. Usually ALD reactions take place in vacuum, but it is also possible to grow thin films by atmospheric pressure ALD, which makes it much easier to adapt the ALD reaction to other industrial processes. Especially in the semiconductor industry, it might be vital not to grow thin films on the complete substrate but only on parts of it, and this can be achieved by area selective ALD. Atomic layer etching (ALE), the reversed version of ALD is also becoming more and more important in the semiconductor industry. The slow growth rate of ALD can be overcome by coating a large numbers of substrates at the same time, or by using roll-to-roll or spatial ALD technology. The coating of powders is also getting increased interest, and it can be done in fluidized bed or rotary ALD reactors.
As ALD allows deposition of uniform thin films on three dimensional (3D) objects with thickness control of sub-nanometer precision, ALD provides new strategies in modifying the properties of nanoscaled materials and new synthetic routes to novel nanostructures. By now, outstanding results have been achieved by ALD in nanotechnology: preparing or coating nanodots, nanotubes, nanowires, nanolaminates, nanoporous materials, inverse opal structures, various nanocomposites, bionanomaterials, etc.

At the Budapest University of Technology, Department of Inorganic and Analytical Chemistry the ALD research is supported by a several decade long collaboration with the Aalto University (formerly Technical University of Helsinki) and the University of Helsinki, Finland. Both institutes are worldwide leaders in ALD.

At BME the ALD activity now is focused on the programmed preparation of complex, functional nanostructures. As substrates, oxide (e.g. $\mathrm{WO}_{3}, \mathrm{TiO}_{2}, \mathrm{ZnO}$, stb.) nanoparticles, nanofibers, nanosheets, polymer (e.g. PVP, PVA, PMMA) nanofibers and nanoparticles, as well as carbon nanostructures (e.g. fullerene, graphene oxide, carbon nanotubes, carbon aerogels, carbon nanospheres) are used. These are synthesized by various techniques, e.g. thermal decomposition, sol-gel, hydrothermal and electrospinning methods. On the substrates mostly oxide $\left(\mathrm{TiO}_{2}, \mathrm{ZnO}, \mathrm{Al}_{2} \mathrm{O}_{3}\right)$ films are deposited, and core/shell nanoparticles and nanofibers, porous nanostructures, nanotubes, nanocomposites etc. are prepared.

The aim of the group is to explore the interaction between the substrates and the ALD films, and to study how the nanostructure properties (e.g. substrate morphology, structure, composition and ALD film composition, thickness, structure) can be optimized in a planned way for the applications. Up to now, the largest number of results were achieved in photocatalysis and gas sensing; but the group is also active in various other fields (e.g. self-cleaning coating, catalysis, electrochromic films, photovoltaic systems).

Below some examples from the ALD results of the group at $\mathrm{BME}$ are listed. At first the photocatalytic nanostructures are mentioned. By combining electrospinning and ALD, $\mathrm{WO}_{3} / \mathrm{TiO}_{2}$ (Fig. 1) as well as $\mathrm{ZnO} / \mathrm{TiO}_{2}$ as $\mathrm{TiO}_{2} / \mathrm{ZnO}$ core/shell nanofiber composites, and also $\mathrm{TiO}_{2}$ and $\mathrm{ZnO}$ nanotubes were obtained. It was an important result that the group also explored the limitations of using ALD for coating electrospun oxide fibers, i.e. if the coating was too thick it could block the pores of the fibers, reduce the specific surface area and the photocatalytic activity. They explored that ALD nucleation happened in a different way on different $1 \mathrm{D} \mathrm{WO}_{3}$ polymorphs. They were the first to coat a soft biological substrate (i.e. the nanopatterned surface of lotus leaf) by ALD, and this way they obtained a photocatalytic and superhydrophobic lotus/ $\mathrm{TiO}_{2}$ bionanocomposite. The $\mathrm{TiO}_{2}$ layer was grown by low temperature ALD, and thus it was amorphous; however, it still had photocatalytic activity. The photocatalytic property was verified further by growing 
amorphous but still photocatalytic ALD TiO 2 layers on $\mathrm{SiO}_{2}$ nanoparticles (Fig. 3), PMMA nanoparticles, fullerene molecule (Fig. 4), graphene oxide, carbon aerogel and carbon nanoparticles.

The gas sensitivitiy of various ALD prepared oxide nanostructures was also tested, e.g. that of $\mathrm{ZnO} / \mathrm{TiO}_{2}$, $\mathrm{TiO}_{2} / \mathrm{ZnO}$, and $\mathrm{WO}_{3} / \mathrm{TiO}_{2}$ nanofibers, $\mathrm{WO}_{3} / \mathrm{ZnO}$ and $\mathrm{WO}_{3} / \mathrm{Al}_{2} \mathrm{O}_{3}$ nanoparticles, as well as $\mathrm{CNT} / \mathrm{TiO}_{2}, \mathrm{CNT} / \mathrm{ZnO}$, $\mathrm{CNT} / \mathrm{TiO}_{2} / \mathrm{ZnO}$, and $\mathrm{CNT} / \mathrm{ZnO} / \mathrm{TiO}_{2}$ nanotubes. The gas sensing ability of ultrathin $10-20 \mathrm{~nm} \mathrm{ZnO}$ and $\mathrm{TiO}_{2}$ layers grown by ALD was verified by quartz crystal microbalance gas sensors.

As further application, porous and flexible polymer/oxide, i.e. Kapton/ZnO and Kapton $/ \mathrm{Al}_{2} \mathrm{O}_{3}$, micro-channel plate electron detectors were produced by ALD. ALD was used also to discovere the surface nanostructures on the surface of birds feathers contributing to structural coloring.

The group has co-authored two ALD review papers. 